\title{
Dziedzictwo „ufortyfikowanej knajpy” Działalność wybranych hoteli i lokali gastronomicznych Torunia w latach 1920-1939
}

Barbara Zulewska*

Hotele i lokale gastronomiczne były ważną częścią życia codziennego mieszkańców II Rzeczypospolitej. W niektórych regionach kraju sektor usług restauracyjno-noclegowych rozwijał się dynamicznie, co miało związek z wieloma innymi czynnikami, takimi jak oferta turystyczna, transport, położenie geograficzne, a nawet klimat. Zakłady gastronomiczne stanowiły niekiedy miejsca spotkań. Toruń, będący w okresie międzywojennym ważnym ośrodkiem administracyjnym i kulturalnym północnej części państwa, w momencie przyłączenia do Polski posiadał bazę hotelową i restauracyjną. Był to efekt wielowiekowej tradycji związanej z prowadzeniem karczem i zajazdów, która sięgała epoki średniowiecza. Prawdziwy rozkwit toruńskich obiektów noclegowych i gastronomicznych przypadł na dziewiętnaste stulecie, kiedy to miasto między Wisłą a Drwęcą otrzymało miano „ufortyfikowanej knajpy". Nazwa ta łączyła w sobie dwoisty charakter Torunia wojskowy i rozrywkowy. Wtedy też zaczęły powstawać nowoczesne lokale gastronomiczne.

* Barbara Zulewska jest magistrem historii i absolwentką Uniwersytetu Gdańskiego. W 2016 r. obroniła pracę dyplomową pt. „Działalność hoteli i lokali gastronomicznych wybranych miast województwa pomorskiego II Rzeczypospolitej”. Interesuje się historią życia codziennego, z naciskiem na dwudziestolecie międzywojenne. 
W eleganckich kawiarniach, modnych restauracjach, zadymionych knajpach zacieśniano więzy międzyludzkie, gromadzono się w celach politycznych, o czym przypominała po latach prasa regionalna: „cały ruch narodowy na Pomorzu gnieździł się potajemnie w różnych lokalach restauracyjnych, za co wielu restauratorów później cierpiało od władz" " Warto zatem postawić dwa pytania: jak wyglądało życie hoteli i lokali gastronomicznych Torunia w nowych, niepodległościowych realiach oraz co pozostało z dziedzictwa „ufortyfikowanej knajpy”?

Cezury czasowe artykułu wyznaczają daty 1920 (włączenie Torunia do Rzeczypospolitej) i 1939 (wybuch II wojny światowej). Materiał źródłowy stanowią głównie prasa („Dzień Pomorski”, „Słowo Pomorskie"), archiwalia (Akta miasta Torunia 1920-1939), księgi adresowe (Ksiegga adresowa miasta Torunia wraz z Podgórzem i powiatem Toruńwieś 1923, Ksiega adresowa i informacyjna miasta Torunia z 1932 r., Ksiega adresowa miasta Torunia wedtug stanu z czerwca 1936).

\section{Proza życia codziennego}

Początki reorganizacji toruńskiego sektora gastronomiczno-noclegowego, które przypadły na wczesne lata dwudzieste XX w., były niełatwe. Restauratorzy i hotelarze odczuwali każdą zmianę zachodzącą w gospodarce młodego państwa. Rozwojowi usług rekreacyjnych szkodziła przede wszystkim inflacja, która doprowadziła do bankructwa wiele przedsiębiorstw. W $1923 \mathrm{r}$. w Toruniu działały jedynie 42 zakłady gastronomiczne, o 93 mniej niż w 1912 r. $^{2}$ Mniejszy spadek w porównaniu z poprzednim okresem zanotowała branża hotelarska, w której skład wchodziło 14 domów gościnnych (w tym 3 pensjonaty) ${ }^{3}$. Na początku lat trzydziestych zaobserwowano znaczny wzrost liczby kawiarni i restauracji, co miało związek z ustabilizowaniem się sytuacji ekonomicznej.

\footnotetext{
${ }^{1}$ Potrzeby zawodu restauracyjno-hotelarskiego, Dzień Pomorski, 1 II 1930, nr 26, s. 5.

${ }^{2}$ K. Przybyszewski, Toruń w latach Drugiej Rzeczypospolitej (1920-1939). Spoteczeństwo i gospodarka, Torun 1994, s. 123.

${ }^{3}$ Księga adresowa miasta Torunia wraz z Podgórzem i powiatem Toruń-wies 1923, Toruń 1923, s. 21, 451.
} 
Liczba lokali gastronomicznych w Toruniu

\begin{tabular}{|l|c|c|c|}
\hline Rodzaj lokalu & 1923 r. & 1932 r. & 1936 r. \\
\hline $\begin{array}{l}\text { Restauracje } \\
\text { (w tym ogrody restauracyjne) }\end{array}$ & 29 & 98 & 85 \\
\hline Kawiarnie i cukiernie & 13 & 10 & 17 \\
\hline Jadłodajnie & - & 29 & 24 \\
\hline
\end{tabular}

Źródło: Ksiegga adresowa miasta Torunia wraz z Podgórzem i powiatem Toruń-wieś 1923, Toruń 1923, s. 21; Księga adresowa i informacyjna miasta Torunia, opr. A. Krzyżanowski, Toruń 1932, s. 537-538; Księga adresowa miasta Torunia wedlug stanu z czerwca 1936, Toruń 1936, s. 27.

Po 1920 r. doszło również do reform w samych hotelach i lokalach gastronomicznych. Na początku dwudziestego stulecia większość zakładów należała do osób narodowości niemieckiej. Po zmianach granic proporcje te odwróciły się. Na przełomie lat dwudziestych i trzydziestych tylko jeden dom noclegowy należał do Niemców, cała zaś reszta do Polaków ${ }^{4}$. Również nazwy hoteli i restauracji zostały spolonizowane, a jako przykład może posłużyć mieszcząca się przy ulicy Chełmińskiej Polonia, znana wcześniej jako Thorner Hof.

Szczególną uwagę warto zwrócić na stowarzyszenia, które zrzeszały właścicieli lokali gastronomicznych i hoteli. W latach 1920-1939 działało kilka takich organizacji. W początkach dwudziestolecia międzywojennego pracownicy sektora gastronomicznego i hotelarskiego zrzeszali się w Związku Pracowników Gastronomicznych oraz w Stowarzyszeniu Hotelistów i Właścicieli na Torun i Okolicę ${ }^{5}$. Jednak do najważniejszych organizacji należało powstałe później Towarzystwo Restauratorów w Toruniu, któremu przewodził Leon Penkalla ${ }^{6}$. Sku-

\footnotetext{
${ }^{4}$ K. Przybyszewski, op. cit., s. 123.

${ }^{5}$ Organizacja ta, założona w 1920 r., nie miała stałej siedziby.

${ }^{6}$ Leon Penkalla (ur. 1887, zm. 1945): kupiec, restaurator i działacz społeczny. Przewodniczacy i honorowy członek Towarzystwa Restauratorów w Toruniu. Należał do czołowych przedstawicieli toruńskiej gastronomii w okresie międzywojennym. Był współtwórcą Centrali Związków Zawodowych Restauratorów na całą Polskę. Pełnił ponadto ważne funkcje społeczne - m.in. radcy toruńskiej Rady Miejskiej oraz sędziego przysięgłego Sądu Grodzkiego.
} 
piało ono większość restauracji i hoteli, reprezentowało interesy właścicieli lokali przed władzami miejskimi i wojewódzkimi. Członkowie Towarzystwa byli również współorganizatorami imprez masowych, jak choćby obchodów 700-lecia miasta Torunia w 1933 r. Uroczystości związane $\mathrm{z}$ rocznicą trwały kilka dni i stanowiły duże wyzwanie logistyczne dla należących do organizacji domów gościnnych i restauracji. Ze względu na wyjątkowość tego wydarzenia właściciele ustalili jednolite ceny posiłków dla zbiorowych wycieczek oraz także samo menu $^{7}$. Powołano ponadto Komisję Kwaterunkową, która była odpowiedzialna za rozlokowanie gości w poszczególnych hotelach, oraz Komisję Aprowizacyjną zajmującą się przygotowywaniem posiłków w wyznaczonych restauracjach ${ }^{8}$.

Współpraca między lokalami nie ograniczała się jedynie do organizowania obchodów i rocznic. Przez cały okres międzywojenny toruński sektor gastronomiczny zmagał się z wieloma problemami. Do najważniejszych należał ogólnopolski kryzys sektora gastronomicznego, który objawiał się spadkiem obrotów i kurczeniem się ruchu konsumentów. Jak pisał „Dzień Pomorski”:

Powierzchniowo rzecz biorąc, mogłoby się wydawać, że tzw. „ciężkie czasy" nie dotykają zbyt silnie zawodu restauracyjnego - w rzeczywistości jednak kryzys w tym zawodzie jest bardzo ostry, ostrzejszy być może aniżeli w innych gałęziach gospodarczych ${ }^{9}$.

Kolejnym sporym problemem dla kierowników lokali gastronomicznych były opłaty za patenty akcyzowe. Właściciele knajp z wyszynkiem mieli obowiązek rozliczać się przed władzami miejskimi ze sprzedaży napojów alkoholowych. W przypadku restauracji toruńskich sam patent akcyzowy kosztował $200 \mathrm{zl}$, a po podwyżce z 1929 r. - $400 \mathrm{zł}$. Do tej sumy dochodziły pozostałe koszty, np. świadectwo przemysłowe. Ówczesna prasa ostrzegała, że zobowiązania pieniężne „doprowadzić mogły do ruiny szereg mniejszych interesów" ${ }^{\prime 10}$. Z drugiej strony

\footnotetext{
${ }^{7}$ 700-lecie miasta Torunia, Archiwum Państwowe w Toruniu, Akta miasta Torunia (dalej cyt. APT, AmT), 1920-1939, sygn. 3350, k. 126.

${ }^{8}$ Ibid., k. 389.

${ }^{9}$ Pod znakiem kryzysu w restauracjach, Dzień Pomorski, 8 II 1930, nr 32, s. 9.

${ }^{10}$ O zniżenie opłat od patentów akcyzowych, Dzień Pomorski, 12 XII 1929, nr 28, s. 5.
} 
rezygnacja z wyszynku alkoholu także mogłaby zakończyć się bankructwem niektórych przedsiębiorstw gastronomicznych, gdyż największy dochód pochodził ze zbytu napojów wysokoprocentowych.

Obok patentów akcyzowych istniało wiele wyzwań, z którymi musieli sobie poradzić właściciele toruńskich lokali gastronomicznych. Poważnym obciążeniem były inne opłaty, jak choćby podatek obrotowy. Dodatkowo funkcjonowanie restauracji regulowały zasady społeczno-religijne. W okresie Wielkiego Postu obowiązywał zakaz organizowania imprez, co również miało znaczący wpływ na dochody restauracji. Przedstawiciele sektora gastronomicznego próbowali ograniczyć to rozporządzenie do Wielkiego Tygodnia ${ }^{11}$. Inne problemy natury moralno-prawnej wywołała uchwalona w 1920 r. ustawa o ograniczeniach $\mathrm{w}$ sprzedaży napojów alkoholowych (potocznie określana mianem prohibicji $)^{12}$. W Toruniu została ona wprowadzona tylko częściowo i obowiązywała $\mathrm{w}$ soboty od godziny 15 do godziny $10 \mathrm{w}$ niedzielę (tzw. prohibicja niedzielna). Jednak zakaz serwowania alkoholu w sobotnie wieczory oddziaływał negatywnie na prosperowanie lokali gastronomicznych, powodując przede wszystkim spadek dochodów. Z prohibicją walczyło między innymi wspomniane już Towarzystwo Restauratorów. W 1928 r. członkowie tej organizacji tak opisywali zaistniałą sytuację:

W pierwszym rzędzie za niekorzystną dla naszego zawodu uznać należy ustawę antyalkoholową z roku 1920 [...]. Akcja, którą prowadziliśmy już od 9 lat, stała się nie tylko walką o egzystencję, lecz wprost o możliwość pracy i zarobku codziennego tysięcy naszych kolegów, stała się walką o prawo wykonywania zawodu restauracyjnego ${ }^{13}$.

\footnotetext{
${ }^{11}$ Potrzeby zawodu restauracyjno-hotelarskiego, Dzień Pomorski, 1 II 1930, nr 26, s. 5 .

${ }^{12}$ Ustawa z dnia 23 kwietnia 1920 r. o ograniczeniu w sprzedaży napojów alkoholowych wprowadzała przede wszystkim zakaz sprzedawania napojów wysokoprocentowych w niedziele i święta w miejscowościach, w których zarządzono pobór do wojska, oraz w niektórych lokalach gastronomicznych (np. bufetach kolejowych).

${ }^{13}$ Koncesje restauracyjne. Aktualne zagadnienia na Pomorzu, Słowo Pomorskie, 1 XII 1928, nr 278, s. 6.
} 
Ostatecznie ustawa, tak szkodliwa dla sektora gastronomicznego, została zniesiona w czerwcu $1931 \mathrm{r}$.

Mimo wielu trudności, właściciele hoteli, restauracji i kawiarń, szczególnie u schyłku lat dwudziestych, nie mogli narzekać na brak zainteresowania ze strony klientów. O popularności i zapotrzebowaniu na zakłady gastronomiczne świadczyły nie tylko liczby, ale również czekające na gości atrakcje. W miejscowej prasie pojawiały się reklamy lokali i zaproszenia na wydarzenia kulturalne. Oferta danego lokalu, na którą składało się menu i program artystyczny, zależała od jego reputacji. Bez wątpienia do obiektów pierwszej klasy ${ }^{14}$ zaliczano powstałe na przełomie XIX i XX w. hotel i restaurację Polonia, którą w okresie międzywojennym zarządzał Zygmunt Wojdak.

W Polonii znajdowało się 31 pokoi z bieżącą wodą, centralnym ogrzewaniem i telefonem. Do dyspozycji przyjezdnych oddano także garaż $\dot{~}^{15}$. W hotelowej restauracji można było zamówić między innymi „rosół z makaronem, zupę cytrynową, kulebiak ${ }^{16}$, jajka po grecku” czy też „sztukę mięsa z ogórkiem”, a na deser serwowano kawę Mokka ${ }^{17}$. Polonia słynęła przede wszystkim $\mathrm{z}$ organizowanych $\mathrm{w}$ niej wieczorków tanecznych i kabaretowych. W okresie karnawału w restauracji odbywały się okolicznościowe przyjęcia, a największą popularnością cieszył się bal sylwestrowy, czyli „,zabawa i dancing z niespodziankami do rana" ${ }^{18}$. Hotel ponadto odgrywał znaczącą rolę w świecie naukowo-artystycznym międzywojennego Torunia. Do 1932 r. mieściła się w nim biblioteka należąca do Stowarzyszenia Polsko-Francuskiego. Natomiast w latach 1935-1936 w głównym holu wystawiano prace członków Konfraterni Artystów. Przede wszystkim jednak uwagę opinii publicznej przykuwały wieści o niecodziennych i dramatycznych wydarzeniach. Polonia znalazła się w centrum zainteresowania w lu-

\footnotetext{
${ }^{14}$ Lokale gastronomiczne i hotele dzielono na klasy od pierwszej do trzeciej. Poza klasyfikacją funkcjonowało wiele lokali, które zazwyczaj uważano za podrzędne, a nawet niebezpieczne.

${ }^{15}$ Hotele i pensjonaty w Polsce, Warszawa 1939, s. 50.

${ }^{16}$ Kulebiak: danie należące do kuchni kresowej. Jest to pieczony pieróg nadziewany farszem.

${ }^{17}$ 700-lecie miasta Torunia, APT, AmT, 1920-1939, sygn. 3350, k. 157.

${ }^{18}$ W noc sylwestrowa $w$ restauracji Polonia, Słowo Pomorskie, 1 I 1938, nr 1, s. 15.
} 
tym 1930 r., kiedy to w jednym z pokoi samobójstwo popełnił oficer Wojska Polskiego. Sprawie tej dokładnie przyjrzał się „Dzień Pomorski”:

W hotelu Polonja targnął się wczoraj na swe życie wystrzałem z rewolweru kapitan 62 p. p. Konarzewski [...]. Około godziny 7-mej zadzwonił po pokojową i zażądał śniadania [...]. Około godziny 10.45 pokojówka usłyszała z pokoju zajmowanego przez K. huk wystrzału rewolwerowego. Służba hotelowa dobijała się do zamkniętych drzwi, a kiedy je otworzono przedstawił się oczom przybyłych tragiczny widok ${ }^{19}$.

W dalszej części relacji dowodzono, że powodem odebrania sobie życia przez Konarzewskiego był „rozstrój psychiczny”. Biorąc pod uwagę fakt, iż w hotelach nieraz dochodziło do samobójstw, wydarzenie to nie wpłynęło niekorzystnie na dalszą działalność Polonii.

Kolejnym renomowanym ośrodkiem był mieszczący się przy ulicy Mostowej hotel Pod Orłem, reklamowany jako „pierwszorzędny, największy i komfortowy"20. Historia tego domu gościnnego ukazywała ogrom zmian, jakie zaszły po I wojnie światowej nie tylko w branży gastronomiczno-hotelarskiej, ale również w społeczeństwie Torunia. Wcześniej ośrodek funkcjonował pod nazwą Pod Czarnym Orłem i uznawany był za lokal typowo niemiecki, który chętnie odwiedzali wojskowi. $\mathrm{Z}$ tego też powodu Polacy, a szczególnie przedstawiciele inteligencji, byli nieczęstymi gośćmi hotelu ${ }^{21}$.

W okresie międzywojennym w skład oferty hotelu Pod Orłem wchodziło 45 pokoi i restauracja. W porze karnawału na gości czekały atrakcje, takie jak dancingi, rauty i okolicznościowe bale. Dzięki niezwykłej atmosferze był on atrakcyjnym miejscem dla osób korzystających z uroków nocnego Torunia, o czym pisano w jednym z numerów „Dnia Pomorskiego":

Zgiełkliwy jazz-band wabi i nęci. Symfonja świateł, niebieskiego dymku i roztańczonych par. Dookoła szum ludzkich głosów. „Pod Orłem” rojno, gwarno i wesoło [...]. Oklaski, bisy to duet Rovena et Gaslor odtańczył boskie

\footnotetext{
${ }^{19}$ Tragedja ociemniatego oficera. Samobójstwo niewidomego oficera $w$ hotelu „Polonja”, Dzień Pomorski, 14 II 1930, nr 37, s. 8.

${ }^{20}$ Hotel „Pod Ortem”, Dzień Pomorski, 23 XI 1929, nr 12, s. 12.

${ }^{21}$ A. Kortas, Befestigte Kneipe. Toruńskie lokale gastronomiczne $i$ hotele w XIX $i$ na początku XX wieku w świetle ksiag adresowych i lokalnej prasy, Toruń 2011, s. 49-50.
} 
tango. Milutka Rosjaneczka Ada Puti tańczy ślicznie „Morphium”. Oleś pełen humoru śpiewa kuplety i piosenki [...]. Kostiumy wspaniałe. Gruby brzuszek, czarny krawat, marsowa mina dla wszystkich, uprzejmy to gospodarz. Marszczy brwi i klnie na goliznę ${ }^{22}$.

Hotel Pod Orłem uchodził za elegancki i spokojny. Można w nim było wynająć przytulny pokój oraz spędzić czas w gronie innych turystów. Harmonia dnia codziennego została zmącona zimą 1926 r., kiedy to doszło tu do, jak określiła prasa, „krwawego napadu bandyckiego”. Pewnego wieczoru dwóch wykwintnie ubranych mężczyzn próbowało zameldować się Pod Orłem. Swoim niecodziennym zachowaniem, brakiem manier i zawartością walizek zaniepokoili portiera, który wezwał policję. Dalsze wypadki potoczyły się szybko. „Goniec Nadwiślański" relacjonował:

Skoro w hotelu pod „Orłem” zjawiła się policja, podejrzane indywidua znajdowały się jeszcze w westibulu hotelu [...]. Proszę o wykazy osobiste zwrócił się do przybyłych jeden z policjantów. W odpowiedzi na to bandyci błyskawicznie wyjęli rewolwery i szybkim ruchem wymierzyli strzały w stojących funkcjonarjuszy - Skutkiem celnie wymierzonego strzału jeden z funkcjonarjuszy padł trupem na miejscu ${ }^{23}$.

Wydarzenie to wstrząsnęło przebywającymi w hotelu gośćmi, zwłaszcza że winowajcom udało się zbiec z miejsca zbrodni i siać postrach na ulicach miasta. Sprawa została wyciszona, gdyż napastników nie złapano, pomimo zaangażowania w pościg oddziałów policji i wojska. „Bandycki napad” nie przyczynił się do zmiany wizerunku hotelu, który funkcjonował nieprzerwanie do 1939 r., chociaż po tym incydencie personel uważniej przyglądał się nowo przybyłym klientom.

Ostatnim renomowanym toruńskim hotelem były Trzy Korony. W porównaniu z Polonią i Pod Orłem tradycja Trzech Koron sięgała znacznie wcześniej. W zajeździe przebywali król Polski August II Mocny oraz car Rosji Piotr $\mathrm{I}^{24}$. Ośrodek cieszył się szczególną popu-

\footnotetext{
${ }^{22}$ Toruń w nocy, Dzień Pomorski, 7 II 1930, nr 31, s. 6.

${ }^{23}$ Krwawy napad bandycki na policję w Toruniu, Goniec Nadwiślański, 18 II 1926, nr 39, s. 6

${ }^{24}$ Wydarzenia te zostały uwiecznione na tablicach pamiątkowych wiszących obok wejścia do Trzech Koron.
} 
larnością w XIX w. i w przeciwieństwie do hotelu Pod Czarnym Orłem był chętnie odwiedzany przez osoby narodowości polskiej. W latach 1920-1939 Trzy Korony utrzymały swoją pozycję w lokalnym sektorze hotelarskim. Kierownicy ośrodka zmieniali się stosunkowo często. W 1930 r. zarządzał nim pan Pocierznicki, a dwa lata później Władysław Sadowski ${ }^{25}$. Ostatnim właścicielem przed wybuchem wojny był Czesław Ruszkowski. Dewiza tego domu gościnnego brzmiała: „pierwszy i największy hotel w miejscu" 26 . Dysponował on restauracją, w której serwowano przeważnie dania kuchni polskiej. Właściciele zapewniali również, że pracujący w hotelu personel był „skory, grzeczny i uczciwy"27. Pobyt gości nie był mącony żadnymi krwawymi wydarzeniami, a jedyną atrakcją były dancingi i występujący w sali głównej kabaret.

Omawiając temat toruńskich hoteli nie sposób nie wspomnieć o powstałej w $1921 \mathrm{r}$. Zofijówce. Był to niewielki, mieszczący się przy ul. Bydgoskiej, pensjonat, którym zarządzała Kazimiera Żuławska ${ }^{28}$. Zofijówka miała duży wpływ na rozwój kulturalny miasta. Przebywali w niej malarze, ludzie pióra, aktorki teatralne, a także postacie kontrowersyjne, jak Stanisław Ignacy Witkiewicz. Dzięki specyficznej klienteli oraz charyzmatycznej właścicielce Zofijówka stała się salonem artystycznym o duchu i tradycji przechodzącej do historii Młodej Polski. Syn Kazimiery Żuławskiej wspominał:

W naszym domu - który na cześć babki Hanickiej został nazwany „Zofijówką" - matka od razu zorganizowała pensjonat według tradycyjnych zakopiańskich wzorów [...]. Pośród mnóstwa interesujących postaci owego czasu mieszkali w pensjonacie generałowie gruzińscy, komandor polskiej marynarki wojennej $[\ldots]$ i niemal połowa toruńskiego teatru ${ }^{29}$.

\footnotetext{
${ }^{25}$ Księga adresowa i informacyjna miasta Torunia, opr. A. Krzyżanowski, Toruń 1932 , s. 524

${ }^{26}$ Toruń w jednym dniu, Toruń 1921, s. 90

${ }^{27}$ Hotel Trzy Korony, Dzień Pomorski, 11 XI 1929, nr 1, s. 11.

${ }^{28}$ Kazimiera Żuławska (ur. 1883, zm. 1971): właścicielka powstałego w Toruniu w 1921 r. pensjonatu Zofijówka. Pochodziła z Podola. Tłumaczka francuskiej literatury, działaczka społeczna. Podczas II wojny światowej udzielała pomocy osobom pochodzenia żydowskiego, za co została odznaczona medalem Sprawiedliwy Wśród Narodów Świata.

${ }^{29}$ J. Żuławski, Z domu, Warszawa 1978, s. 213.
} 
W pensjonacie organizowano wieczorki towarzyskie i wystawy obrazów Witkacego (artysta swoim stylem życia nierzadko wprawiał w zakłopotanie pozostałych gości). Ponadto w Zofijówce zbierali się członkowie Konfraterni Artystów, którzy, korzystając z uprzejmości właścicielki, nawiązywali kontakty z przedstawicielami instytucji kulturalnych. Chociaż pensjonat funkcjonował tylko 5 lat, był ważnym punktem turystycznym na mapie międzywojennego Torunia ${ }^{30}$.

Obok pierwszorzędnych hoteli i restauracji w międzywojennym Toruniu działało wiele mniejszych lokali i knajp. Zaspokajały one potrzeby rozrywkowe mieszkańców, oferując niedrogie potrawy i atrakcje w postaci dancingów i wieczorków towarzyskich. W większości placówek gastronomicznych królowała kuchnia polska. I tak w mieszczącym się przy ulicy Remontowej barze Satyr podawano „rosół z kaszką i zupę wiosenną, sztukę mięsa z sałatką kartoflaną, wieprzowinę duszoną i pierożki leniwe $\mathrm{z}$ masłem”, a na deser "mus owocowy ${ }^{31}$. Natomiast w lokalu należącym do A. Goślińskiego (ul. Szeroka) prócz „rosołu z jarzynami” klienci mieli możliwość spróbowania „,bitek w śmietanie, szynki w sosie musztardowym i mostka po wiedeńsku"32. Sporym powodzeniem cieszyły się zwłaszcza domowe obiady, które serwowały restauracje Astorja (ul. Łazienna) i Złoty Róg, gdzie dodatkowo proponowano gościom „zimne i ciepłe zakąski”33.

Wśród drugorzędnych toruńskich lokali okresu międzywojennego najmodniejsza była mieszcząca się przy ulicy Konopnickiej Esplanada. Kawiarnia zyskała sławę przede wszystkim dzięki często odbywającym się w niej dancingom i występom artystycznym. Działała całą noc, kusząc niskimi cenami oraz „doskonałą kuchnią"34. Esplanada miała szeroką ofertę - $\mathrm{z}$ usług lokalu korzystały zarówno rodziny z dziećmi (do godziny 19 obowiązywał program familijny), jak i osoby poszukujące wieczornych rozrywek w postaci koncertów i popisów

\footnotetext{
${ }^{30}$ M. Czarnecki, Dni i noce w Zofijówce, Gazeta Wyborcza Torun, 4 III 2011, nr 63, s. $4-5$.

700-lecie miasta Torunia, k. 150.

${ }^{32}$ Ibid., k. 152.

${ }^{33}$ Śniadania i kawiarnia „Zloty Róg”, Dzień Pomorski, 5 XII 1929, nr 22, s. 8.

${ }^{34}$ Five o'clock tea, Dziennik Pomorski, 14 I 1930, nr 10, s. 5.
} 
kabareciarzy. Czas gościom zazwyczaj umilała orkiestra Del Rio ${ }^{35}$. W Esplanadzie odbywały się również często „parady humoru”, a do stałego repertuaru należał five o'clock.

Życie codzienne toruńskich lokali gastronomicznych toczyło się według standardowego schematu. W większości restauracji i kawiarni odbywały się okolicznościowe przyjęcia i niemal wszystkie reklamowały się jako pierwszorzędne i najlepsze. Jednak nieskazitelną opinią i wysokim poziomem mogło poszczycić się bardzo mało lokali. Europejskim standardom próbowała sprostać między innymi kawiarnia Pomorzanka, którą w 1929 r. właściciel gruntownie wyremontował, likwidując wcześniejsze niedostatki ${ }^{36}$.

Wielu torunian korzystało także z usług mieszczącego się na Podzamczu ogrodu-restauracji Strzelnica. Lokal ten rozpoczął działalność w 1899 r. i od początku chętnie odwiedzany był przez Polaków (zbierały się w nim polskie organizacje, np. Towarzystwo Pożyczkowe ${ }^{37}$ ). W latach 1920-1939 tradycja urządzania w Strzelnicy spotkań przeróżnych grup i związków była podtrzymywana. W restauracji zbierali się między innymi podoficerowie rezerwy w celu wysłuchania referatów (np. w styczniu 1930 r. był to odczyt Szpiegostwo niemieckie) ${ }^{38}$. Dodatkowo lokal uatrakcyjniały odbywające się w nim przyjęcia. Co roku $\mathrm{w}$ grudniu organizowano uroczystość gwiazdkową dla rodzin urzędników miejskich. Jak relacjonował „Dzień Pomorski”, punktem kulminacyjnym spotkania były „zabawa i rozdanie podarków ok. 130 dzieciom"39. W karnawale w sali Strzelnicy odbywały się zabawy i rauty, w których brali udział przedstawiciele różnych grup zawodowych, jak choćby drukarze czy drogerzyści. Restauracja cieszyła się popularnością zarówno wśród inteligencji, jak i pracowników fizycznych.

Podobną rolę do Strzelnicy odgrywał kolejny ogród-restauracja, mianowicie Park Wiktorii (ul. Grudziądzka), który także rozpoczął działalność w dziewiętnastym stuleciu. Początek okresu międzywojennego

\footnotetext{
${ }^{35}$ Esplanada, Dzień Pomorski, 1811 1929, nr 7, s. 8.

${ }^{36}$ Pomorzanka w nowej szacie, Dzień Pomorski, 27 XI 1929, nr 15, s. 5.

${ }^{37}$ A. Kortas, op. cit., s. 152.

${ }^{38}$ Zebranie Zwiazku Podoficerów Rezerwy w Toruniu, Dzień Pomorski, 5 I 1930, nr 4. s. 7.

${ }^{39}$ Tradycyjna uroczystość gwiazdkowa, Dzień Pomorski, 30 XII 1930, nr 41, s. 5.
} 
był burzliwy dla tego lokalu. Odbywający się na początku stycznia 1920 r. występ zespołu Teatru Polskiego został spacyfikowany przez grupę stacjonujących $\mathrm{w}$ Toruniu żołnierzy niemieckich. Jak podała "Gazeta Toruńska":

W czasie przedstawienia drugiego aktu około godziny 9 wieczorem wtargnęło przez główne wejście, nie posiadając kart wstępu, 4 żołnierzy należących do 21 pułku piechoty, którzy hałasem przeszkadzali przedstawieniu [...] pół godziny [później - B. Z.] znów wpadli na salę żołnierze i nie zważając na porządkowego, który stał przy drzwiach [...] wołali głośno, że oczyszczą salę z Polaków [...] hałasując i krzycząc „Raus mit den Polaken”. Wołając to, żołdactwo zaczęło rzucać krzesłami na cisnącą się w popłochu publiczność, składającą się przeważnie z kobiet i dzieci [...]. Gospodarzowi naniszczono sporo krzeseł, które thuszcza żołnierska całą siłą rzucała na gromadę. Prócz tego potłuczono mnóstwo $\mathrm{szyb}^{40}$.

Sytuację udało się opanować, choć, jak podaje dalej gazeta, osoby odpowiedzialne za porządek w mieście (posterunek wojskowy) przybyły po czasie, kiedy sprawcy zajścia zdążyli opuścić restaurację. Zachowanie niemieckich żołnierzy było podyktowane między innymi polskim charakterem Parku Wiktorii. Już w 1919 r. w restauracji urządzano patriotyczne wiece, których celem było wsparcie sprawy Rzeczypospolitej na arenie międzynarodowej. Przykładowo w początkach tego roku zorganizowano wiec, którego członkowie opowiadali się za włączeniem Galicji Wschodniej do Rzeczypospolitej ${ }^{41}$.

Po ustabilizowaniu się sytuacji politycznej i społecznej, w Parku Wiktorii nie zaobserwowano już niepokojących lub gwałtownych wydarzeń. Tak jak Strzelnicę, Park odwiedzały rozmaite grupy społeczne. W Boże Narodzenie salę restauracyjną wynajmowała Filia Piekarzy, Cukierników i Piernikarzy, która organizowała dla zainteresowanych świąteczną zabawę $e^{42}$ Z okazji Gwiazdki w Parku Wiktorii zbierał się ponadto Związek Inwalidów Wojennych.

Powyższe przykłady świadczą o tym, że hotele i lokale gastronomiczne międzywojennego Torunia miały urozmaiconą ofertę i jedno-

\footnotetext{
${ }^{40}$ Napaść żolnierzy na Polaków, Gazeta Toruńska, 6 I 1920, nr 4, s. 1.

${ }^{41}$ Wielki wiec, Gazeta Toruńska, 10 I 1920, nr 7, s. 2.

${ }^{42}$ Filja Piekarzy, Cukierników i Piernikarzy, Dzień Pomorski, 24 XII 1929, nr 38, s. 11.
} 
cześnie, szczególnie w początkach lat dwudziestych XX w., pełniły ważne funkcje społeczne i kulturowe. Pomimo jednak ogólnie pozytywnych opinii i reklam zachęcających do odwiedzin, część restauracji miała bardzo duże problemy ze spełnieniem podstawowych warunków, dotyczących utrzymania czystości i wymogów sanitarnych.

\section{Stan sanitarny i przestrzeganie prawa w toruńskich lokalach gastronomicznych i hotelach}

Najważniejszym elementem, który jednocześnie umożliwiał działalność lokali gastronomicznych i hoteli, było przestrzeganie istniejącego prawa. W 1929 r. wydano Rozporzadzenie Policyjne Wojewody Pomorskiego $w$ sprawie przepisów sanitarnych dla hoteli, pensjonatów $i$ domów zajezdnych. Rozporządzenie objęło wszystkie wioski i miasta znajdujące się w obrębie województwa, w tym również Toruń. Dokument zawierał dokładną instrukcję, jak powinny być prowadzone wzorowy hotel i restauracja. Przede wszystkim, co nie wzbudzało żadnych wątpliwości, właściciele i personel mieli obowiązek utrzymywać swoje miejsce pracy w jak największym porządku, tj. przestrzegać zasad higieny i bezpieczeństwa. Według rozporządzenia, aby funkcjonowanie danego hotelu i zakładu gastronomicznego mogło być legalne, przyszli gospodarze musieli postarać się o uzyskanie koncesji oraz umożliwić oględziny policyjno-sanitarne ${ }^{43}$. Kolejną istotną kwestią było wydzielenie części budynku w celu utworzenia toalet (osobnych dla kobiet i mężczyzn). Każda $\mathrm{z}$ nich powinna mieć dostęp do światła dziennego oraz zainstalowaną wentylację. Jeden $\mathrm{z}$ paragrafów poświęcono również pomieszczeniom do wynajęcia. Wedle rozporządzenia:

§ 5. Pokoje mieszkalne nie mogą mieścić się w suterenach, winny być suche, dostatecznie oświetlone i mieć należyte urządzenia do ogrzewania i przewietrzenia. Temperatura $\mathrm{w}$ tych pokojach $\mathrm{w}$ chłodnej porze roku nie

\footnotetext{
${ }^{43}$ Rozporządzenie Policyjne Wojewody Pomorskiego w sprawie przepisów sanitarnych dla hoteli, pensjonatów i domów zajezdnych, Pomorski Dziennik Wojewódzki 1929, nr 16, s. 211.
} 
powinna być niższa niż 17 stopni Celzjusza. Sufity powinny być gładkie i jasne, pomalowane farbą olejną; obok łóżka i umywalni pomalowanie ścian farbą olejną jest obowiązkowe. Podłogi powinny być gładkie i szczelne etc. ${ }^{44}$

Dokument regulował także kilka innych kwestii, jak szerokość korytarzy (minimum 1,75 m), obowiązek ustawienia w każdym pomieszczeniu (w tym również $\mathrm{w}$ holu przy schodach) napełnionych wodą spluwaczek czy umieszczenie przed drzwiami wejściowymi wycieraczki. Sporo uwagi poświęcono kuchni, która musiała być przestronna, widna, dobrze wentylowana. W porze letniej na okna kuchenne powinny być zakładane ,gęste siatki zabezpieczające pomieszczenie od dostępu owadów" 45 . Władze zastrzegały, że w pomieszczeniach gospodarczych nie wolno było spać, przechowywać odzieży czy też wpuszczać do nich zwierząt. Ubiór pracowników miał się składać z białych, czystych fartuchów z rękawami. Kucharzom i kucharkom dodatkowo zalecano noszenie „,czapek osłaniających włosy”46. Osoby zatrudnione w hotelach i restauracjach poddawano okresowym badaniom lekarskim (zakazywano przyjmowania do pracy ludzi cierpiących na schorzenia skóry, gruźlicę i inne choroby zakaźne). Za niedopuszczalne uważano tolerowanie robactwa (szczególnie pluskiew i wszy), które należało $\mathrm{w}$ trybie natychmiastowym wytępić. Za nieprzestrzeganie ustalonych zasad groziła grzywna w wysokości $60 \mathrm{zł} \mathrm{(w} \mathrm{przypadku}$ nieuiszczenia nałożonej opłaty karę zamieniano na areszt) ${ }^{47}$. Jeżeli stan danej placówki gastronomicznej nie zmieniał się, lokal zamykano. Chociaż przepisy sanitarne i budowlane zostały przedstawione klarownie, przestrzeganie ich stanowiło dla większości toruńskich lokali gastronomicznych i hoteli duży problem. Mimo na pierwszy rzut oka schludnego wnętrza sal, zaplecza jak, i kuchni, lokale często nie spełniały ustalonych prawnie norm ${ }^{48}$. Kontrolowaniem kondycji restaura-

${ }^{44}$ Ibid., s. 212.

${ }^{45}$ Ibid.

${ }^{46}$ Ibid.

${ }^{47}$ Ibid., s. 213.

${ }^{48}$ T. Krzemiński, Krajobraz higieniczno-estetyczny miast $i$ wsi pomorskich $w d w u-$ dziestoleciu międzywojennym, Zapiski Historyczne, t. 77: 2012, z. 2, s. 45. http://www. zapiskihistoryczne.pl/files/issues/1eb402d5ae0eeb6cbcfd66d80a10ed30_ZH_2012_2_ KrzeminskiN.pdf, (dostęp 04.04.2017). 
cji i domów wypoczynkowych zajmowała się Komisja Sanitarna Miasta Torunia. Raporty owej komisji, dotyczące funkcjonowania poszczególnych placówek, wskazywały na wyraźne zaniedbania. Największe trudności z utrzymaniem ładu i czystości mieli właściciele drugorzędnych lokali.

Sprawozdania z wizytacji małych i średnich restauracji i jadłodajni zawierały wiele uwag dotyczących jakości oferty i stanu pomieszczeń. I tak w mieszczącym się przy ulicy Narutowicza lokalu Karola Franka „ściany i sufit brudne, próg przy wejściu do składu uszkodzony”49. Były to drobne niedociągnięcia, które gospodarz musiał usunąć w ciągu 30 dni. W innej restauracji, zlokalizowanej przy ulicy Mickiewicza, stwierdzono brak przepisowego urządzenia do płukania naczyń oraz ustępu dla mężczyzn ${ }^{50}$. Członkowie komisji sanitarnej zwracali również uwagę na nieczytelne szyldy, które zwykle zasłaniała gruba warstwa kurzu. Kierownicy restauracji nagminnie zapominali o instalowaniu zlewów kuchennych, nie wiadomo było, gdzie i w jaki sposób czyszczono brudną zastawę stołową. Odnotowywano także niewielkie zaniedbania, np. nieprzykryte mleko, leżący na półkach brudny papier czy niewyrzucone śmieci. Nierzadko upominano właścicieli, aby naprawili uszkodzoną podłogę lub wyszorowali otłuszczone ściany. O ile w głównych pomieszczeniach małych restauracji starano się utrzymać względny porządek, o tyle składziki i komórki „były zaśmiecone oraz pełne starych naczyń" ${ }^{\prime 51}$.

Kolejną ważną kwestią, z którą nie radzili sobie gospodarze i pracownicy, było odpowiednie przechowywanie artykułów spożywczych. W kawiarniach nagminnie pozostawiano wyroby cukiernicze na bufecie bez odpowiedniego zabezpieczenia, przez co miały do nich dostęp owady. Przed inwazją insektów nie chroniły także siatki na oknach, gdyż po prostu ich nie zamontowywano. Na stołach dla gości umieszczano kosze z odsłoniętym pieczywem, które w szybkim tempie wysychało lub stawało się pożywieniem dla much. Również resztki posiłków należało jak najszybciej usunąć z obrębu lokalu, lecz wbrew przepi-

\footnotetext{
${ }^{49}$ Kontrola hoteli i restauracji, APT, AmT, 1920-1939, sygn. 3680, k. 2.

${ }^{50}$ Ibid., k. 9.

${ }^{51}$ Ibid., k. 43
} 
som czyniono to sporadycznie. Na przykład na podwórzu jednej z restauracji, tuż pod kuchennymi oknami, stała beczka pełna gnijących odpadów $^{52}$. W pewnym lokalu zbagatelizowano nawet leżące na poplamionych misach nieświeże śledzie. Pracownicy nie przejawiali ponadto większego zainteresowania zużytymi garnkami, które chowano na zapleczu i zapominano o nich aż do momentu kontroli sanitarnej. Dodatkowo w przeważającej liczbie knajp brakowało spluwaczek.

Na podstawie dostępnych źródeł stwierdzić można, że osoby odpowiedzialne za działalność lokali i hoteli lekceważyły nakaz dbania o łazienki. W toaletach dla gości nie zakładano umywalek ani gruntownie ich nie sprzątano. Czasami ustępy dla obojga płci lokowano w ciasnych i ciemnych zakątkach budynku. Jeżeli już wydzielano osobne pomieszczenia, to $w$ tych dla mężczyzn nie montowano pisuarów. Sporadycznie zaopatrywano toalety w ręczniki i mydła. Przykładowo w łazienkach hotelu Europa nie było żadnego oświetlenia (nawet sztucznego), a ściany w nich były brudne, sufity niepomalowane ${ }^{53}$. Wydawać by się mogło, że trudności w utrzymaniu należytego porządku nie dotyczyły znanych i chętnie odwiedzanych lokali. W rzeczywistości jednak stan pierwszorzędnych restauracji i hoteli daleki był od ustalonych norm. Za symbol skrajnego zaniedbania mogła posłużyć oberża Pod Modrym Fartuchem. Istniała ona nieprzerwanie od XV w., a co za tym idzie, miała barwną historię (odpoczywać w niej miał król polski Kazimierz Jagiellończyk). Modremu Fartuchowi poświęcono nawet wiersz:

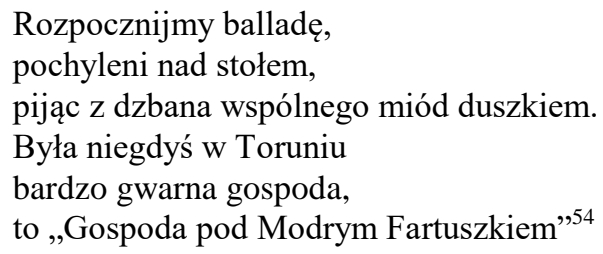

\footnotetext{
${ }^{52}$ Ibid., k. 54.

${ }^{53}$ Ibid., k. 211.

${ }^{54}$ T. Petrykowski, Pod Modrym Fartuszkiem, [w:] Toruń w opisach literackich. Głosy wieków, opr. J. Przybyłowa, Toruń 1973, s. 82.
} 
Mimo wielowiekowej tradycji, w okresie międzywojennym kondycja gospody bardzo się pogorszyła. W protokole sporządzonym w lipcu 1929 r. stwierdzono:

Na ogół w salach restauracyjnych i pokojach hotelowych panuje brud i niechlujstwo. Kuchnia restauracyjna mieści się w ubikacji nie nadającej się pod żadnym względem na ten cel. Sień i wejście do kuchni ciemne, nie oświetlone należycie i ciasne. Służba w kuchni nie należycie ubrana, brak siatek w oknach, w kuchni gotuje się cuchnące kości, skutkiem czego rozchodzi się przykra woń po całym hotelu [...]. Pokoje dla przyjezdnych brudne, ściany i sufity dawno nie odnawiane [...]. Podłoga balkonu częściowo przegniła. Grozi bezpieczeństwu publicznemu ${ }^{55}$.

Przed właścicielem Modrego Fartucha stanęło zadanie gruntownego wyremontowania oberży. Dzięki spisowi przedsiębiorstw z 1932 r. wiadomo, że gospody nie zamknięto, czyli kontrola przyniosła zapewne pozytywne efekty.

O tym, że w pierwszorzędnych lokalach dochodziło do uchybień, informowali sami klienci. Skarżono się głównie na brak czystości i nieświeże potrawy. Problemy z wdrożeniem w życie przepisów wojewódzkiego rozporządzenia miała placówka Pod Orłem. Pracownicy i gospodarz ignorowali fakt, iż piece były nieszczelne i kopcące, a w pomieszczeniach dla służby zalegały śmieci. W części pokoi ściany wciąż były wytapetowane ${ }^{56}$. W gorszej sytuacji znajdował się dom wypoczynkowy Trzy Korony. Nie dbano o porządek w kuchni, podłogi były nierówne. Na podwórzu składowano stare butelki i inne niepotrzebne rzeczy. Trzem Koronom zarzucono również zbyt wąskie korytarze i wspólne dla obojga płci łazienki. Natomiast w hotelu Polonia sprzątano pokoje, ale zbagatelizowano kwestię kuchni, która mieściła się w suterenach i była „niedostatecznie oświetlona" ${ }^{, 57}$.

O swój lokal nie troszczył się należycie także kierownik Pomorzanki. Kawiarnia, w której organizowano dla gości występy artystyczne i dancingi, znajdowała się, według komisji, w stanie zaniedbania. Woda z ubikacji wylewała się na podłogę i podtapiała sień. $\mathrm{Na}$

\footnotetext{
${ }^{55}$ Kontrola hoteli i restauracji, k. 114.

${ }^{56}$ Ibid., k. 133.

${ }^{57}$ Ibid., k. 371
} 
stole, na którym przygotowywano wyroby cukiernicze, leżały rupiecie, a naczynia były zniszczone. Prawdziwą grozę budziły pomieszczenia dla służby, w których zalęgły się pluskwy ${ }^{58}$. Warunki panujące w niektórych lokalach przeszkadzały samemu personelowi. Kucharka zatrudniona w jadłodajni przy ulicy Prostej napisała donos na swojego pracodawcę, zarzucając mu, że pozwalał serwować gościom mięso przywożone $\mathrm{w}$ zarobaczonych workach ${ }^{59}$. Inny informator oskarżał jedną $\mathrm{z}$ restauratorek o urządzenie sobie sypialni $\mathrm{z}$ ubikacji ${ }^{60}$. Do władz wpływały również zawiadomienia o prowadzeniu nielegalnych przedsiębiorstw gastronomicznych, które znajdowały się zazwyczaj w prywatnych domach. Ich właściciele nie mieli koncesji na wyszynk napojów alkoholowych. Goście często utrudniali życie lokatorom, hałasując $w$ godzinach nocnych i załatwiając potrzeby fizjologiczne na podwórzu. Bezprawnie prowadzone lokale pełniły niekiedy funkcję domów publicznych. Przepisy, które łamano, dotyczyły ponadto zatrudnienia kobiet w placówkach gastronomicznych. Kelnerki nierzadko pracowały też jako dziewczyny do towarzystwa. Prostytucja była zatem obecna zarówno na ulicy, jak i w knajpach, a widok nierządnicy oferującej swoje wdzięki w restauracji nie budził szczególnego zdziwienia $^{61}$.

\section{Knajpa knajpie nierówna}

W kawiarnianych mrokach żyją całe grupy ludzi, tworząc charakterystyczną i specjalną publiczność, żądną ruchu i oddechu Europy, co wionie ze szpalt zadrukowanej bibuły, spragnioną plotek wielkiego miasta, a przede wszystkim życia błyskotliwego, na falach drgającego światła, w arabeskach dymu, wśród nawoływań kelnerów ${ }^{62}$.

\footnotetext{
${ }^{58}$ Ibid., k. 22.

${ }^{59}$ Stan sanitarny jadłodajni, APT, AmT, 1920-1939, sygn. 3690, k. 4.

${ }^{60}$ Ibid., k. 4.

${ }^{61}$ T. Krzemiński, Prostytucja w międzywojennym Toruniu: szkic zagadnienia, Rocznik Toruński, R. 40, 2013, s. 71: http://bazhum.muzhp.pl/media//files/ Rocznik_ Torunski/Rocznik_Torunski-r2013-t40/Rocznik_Torunski-r2013-t40-s61-76/Rocznik_ Torunski-r2013-t40-s61-76.pdf, (dostęp 04.04.2017).

${ }^{62}$ J. Jaworski, Lwów stary $i$ wczorajszy, Lwów 1911, s. 219.
} 
Cytat ten, choć pochodzi z 1911 r. i dotyczy Lwowa, śmiało można odnieść do lokali gastronomicznych międzywojennego Torunia. Goście i mieszkańcy spotykali się w reprezentatywnych restauracjach, wynajmowali pokoje w hotelach i niewielkich pensjonatach, spędzali wolny czas w zadymionych barach i knajpach o wątpliwej reputacji. I choć, jak zaznaczył w swoich wspomnieniach Juliusz Żuławski: „Toruń jaśniał w tych czasach wszystkimi barwami życia artystycznego i kulturalnego Polski", nie wszystkie zakłady gastronomiczne przetrwały trzęsienie ziemi, jakim było znalezienie się w granicach młodego państwa. Warto zaznaczyć, że w ciągu dziewiętnastu lat w Toruniu powstał tylko jeden nowy dom gościnny. Nieco większą dynamikę przejawiały toruńskie lokale gastronomiczne, lecz ich rozwój hamowały brak przestrzegania prawa przez właścicieli i niestosowanie się do zasad sanitarno-porządkowych. Niemniej jednak restauratorzy toruńscy tworzyli stowarzyszenia i związki zawodowe oraz starali się promować swoje lokale poprzez reklamy w prasie i współorganizowanie wydarzeń masowych, jak na przykład 700-lecie miasta. Niech o dziedzictwie „ufortyfikowanej knajpy" świadczy fakt, że część działających przed wojną hoteli przetrwała do czasów dzisiejszych (Trzy Korony, Polonia), a turyści mają okazję wstąpić do słynnego Modrego Fartucha.

\section{Bibliografia}

Źródła

Archiwalne

Archiwum Państwowe w Toruniu. Akta miasta Torunia 1920-1939, 3350, 3680, 3690.

Dokumenty wydane drukiem

Hotele i pensjonaty w Polsce, Warszawa 1939.

Pomorski Dziennik Wojewódzki 1929, nr 16.

Prasa

Dzień Pomorski 1929, 1930.

Gazeta Toruńska 1920.

Gazeta Wyborcza Torun 2011.

Goniec Nadwiślański 1926.

Słowo Pomorskie 1928, 1938. 
Wspomnienia

Żuławski J., Z domu, Warszawa 1978.

Księgi adresowe

Księga adresowa i informacyjna miasta Torunia, opr. A. Krzyżanowski, Toruń 1932.

Księga adresowa miasta Torunia wedlug stanu z czerwca 1936, Toruń 1936.

Księga adresowa miasta Torunia wraz z Podgórzem i powiatem Toruń-wieś 1923, Toruń 1923.

Opracowania

Kortas A., Befestigte Kneipe. Toruńskie lokale gastronomiczne i hotele w XIX wieku i na poczatku XX wieku w świetle ksiag adresowych i lokalnej prasy, Toruń 2011.

Krzemiński T., Krajobraz higieniczno-estetyczny miast $i$ wsi pomorskich $w d w u d z i e s t o l e c i u$ międzywojennym, Zapiski Historyczne, t. 77: 2012, z. 2.

Krzemiński T., Prostytucja $w$ międzywojennym Toruniu: szkic zagadnienia, Rocznik Toruński, R. 40, 2013.

Przybyszewski K., Toruń w latach Drugiej Rzeczypospolitej (1920-1939). Społeczeństwo i gospodarka, Toruń 1994.

Streszczenie: Hotele i lokale gastronomiczne były ważną częścią życia codziennego mieszkańców II Rzeczypospolitej. Zakłady gastronomiczne stanowiły niekiedy miejsca spotkań. Toruń będący w okresie międzywojennym ważnym ośrodkiem administracyjnym i kulturalnym północnej części państwa, w momencie przyłączenia do Polski posiadał bazę hotelową i restauracyjną. W eleganckich kawiarniach, modnych cukierniach, zadymionych i szemranych knajpach zacieśniano więzy międzyludzkie. Torunianie chętnie korzystali z oferty licznych lokali, jedząc, pijąc, słuchając koncertów, będąc niekiedy świadkami skandali obyczajowych i przestępstw.

Artykuł ma na celu ukazanie działalności wybranych hoteli i lokali gastronomicznych międzywojennego Torunia zarówno $\mathrm{z}$ tej jasnej, jak i ciemnej strony. Na materiał źródłowy składają się m.in. prasa regionalna („Dzień Pomorski”, „Słowo Pomorskie”) i archiwalia (Akta miasta Torunia 1920-1939). 
The heritage of „The fortified restaurant”. The activity of selected hotels and restaurants of Torun in the years 1920-1939

\begin{abstract}
Hotels and restaurants constituted an important part of everyday life in the times of the Second Republic of Poland. Restaurants were places where members of a given community gathered. Torun, which was an important administrative and cultural centre of the northern part of Poland, had already had a sufficient number of hotels and restaurant when it was incorporated into Poland. In elegant cafeterias, trendy confectioneries and restaurants filled with cigarette smoke people got to know each other. Inhabitants of Torun went to restaurants to eat, drink, listen to concerts; sometimes they witnessed scandals and crimes.

The aim of the article is to show selected hotels and restaurants of the interwar Torun both in their positive and negative light. The source material consists in regional press („Dzień Pomorski”, „Słowo Pomorskie”) and archival files (the Files of the City of Torun 1920-1939).
\end{abstract}

\title{
Das Erbe der „Kneipenfestung”. Der Betrieb ausgewählter Hotels und gastronomischer Lokale in Thorn in den Jahren 1920-1939
}

Zusammenfassung: Hotels und Gaststätten waren ein wichtiger Teil des Alltagslebens der Einwohner der zweiten Republik. Die Gastronomiebetriebe waren oft ein Begegnungszentrum für die Bevölkerung des jeweiligen Ortes. Thorn war in der Zwischenkriegszeit ein wichtiges Verwaltungs- und Kulturzentrum im nördlichen Teil des Staats und besaß zum Zeitpunkt des Anschlusses an Polen einen Bestand an Hotels und Restaurants. In eleganten Cafés, angesagten Konditoreien, in verrauchten und dunkeln Kneipen wurden menschliche Beziehungen angeknüpft. Die Thorner machten gern von den Angeboten zahlreicher Lokale Gebrauch, sie aßen, tranken, hörten Konzerte und waren hin und wieder Zeugen von pikanten Skandalen und Verbrechen.

Der Artikel zeigt den Betrieb von ausgewählten Hotels und Gaststätten im Thorn der Zwischenkriegszeit sowohl von dieser lichten wie von der dunkeln Seite. Zum Quellenmaterial gehören u. a. die regionale Presse („Dzień Pomorski”, „Słowo Pomorskie”) und Archivalien (Akten der Stadt Thorn 19201939). 
Słowa kluczowe: Toruń, hotel, lokal gastronomiczny, restauracja, kawiarnia, knajpa, okres międzywojenny

Keywords: Toruń, hotel, gastronomic premises, restaurant, cafeteria, pub, the interwar period

Schlüsselwörter: Thorn, Hotel, gastronomisches Lokal, Restaurant, Café, Kneipe, Zwischenkriegszeit 